This item was submitted to Loughborough's Research Repository by the author.

Items in Figshare are protected by copyright, with all rights reserved, unless otherwise indicated.

\title{
John Piper's modernist scenography
}

PLEASE CITE THE PUBLISHED VERSION

https://doi.org/10.3366/mod.2016.0136

PUBLISHER

Edinburgh University Press

VERSION

AM (Accepted Manuscript)

\section{PUBLISHER STATEMENT}

This work is made available according to the conditions of the Creative Commons Attribution-NonCommercialNoDerivatives 4.0 International (CC BY-NC-ND 4.0) licence. Full details of this licence are available at: https://creativecommons.org/licenses/by-nc-nd/4.0/

\section{LICENCE}

CC BY-NC-ND 4.0

\section{REPOSITORY RECORD}

Warden, Claire. 2019. “John Piper's Modernist Scenography”. figshare. https://hdl.handle.net/2134/37562. 


\section{John Piper's Modernist Scenography \\ Dr Claire Warden \\ Modernist Cultures (June 2016)}

\section{Painting, poetry and performance}

In 1949 artist John Piper completed a two-colour illustration for Sir George Sitwell's romantic celebration of horticultural beauty, On the Making of Gardens. ${ }^{1}$ In it a statue of a woman painted white reclines against a pillar, with a stone staircase ascending from left to right (in stage terms). The background is rather more shadowy: indistinct tree shapes against a pale peach wash. The illustration resembles a stage set: one can imagine actors climbing the stair, passing the statue to be enveloped in the encroaching darkness beyond.

Piper's enduring canon of work is particularly diverse, exhibiting a Continental European sense of abstraction during the 1930s before turning more decisively towards British landscape and architecture. All these phases clearly demonstrate the intense theatricality of Piper's work, fundamental in his grandest seascapes and smallest bookplates, his most geometrical canvases and most atmospheric English country house paintings. ${ }^{2}$ Indeed, John Russell claims Piper's art has an innate dramatic quality:

When people say something is 'theatrical', they often mean that it is stagey heightened for effect, and with no moral or emotional thrust behind it. John Piper's work has often been theatrical in the other, truer, more challenging sense. It is a matter, in other words, of timing and placement, lighting and concentration, ellipsis and subliminal hint. ${ }^{3}$

This subtle theatricality unites Piper's diverse oeuvre, a fact noted by his contemporaries as early as the mid 1930s. In the November 1935 edition of Axis (edited by Myfanwy Evans, later Piper's wife), German art historian Herta Wescher discusses Piper's work: The artist's object has ceased to be the putting together of planes so as to form a mosaic founded by a law of harmony. The segments become, as it were, the wings which an impassioned stage-manager manipulates, waving them backwards and forwards, alternating light and darkness, leaving here a gap, there a perspective. $^{4}$

Intrinsic to the work of artists such as Piper, Wescher reflects, is a theatrical dynamism. Theatricality, in Wescher's description, disturbs the peace of the artwork, disordering shapes, lines and objects in favour of exposing lacunae or revealing new, previously 
unexplored panorama. An imagined stage manager handles and moves the fragments without necessarily achieving (or even wanting to achieve) scenic unity. This is as true for Piper's abstractions as for his landscapes.

While his theatrical paintings receive much acclaim, Piper's theatre design work remains less well-known, with the exception of his collaborations with Benjamin Britten on productions like Peter Grimes (1945), Rape of Lucretia (1946) and Turn of the Screw (1954 for which Myfanwy Piper wrote the libretto). Britten admired Piper's designs enormously, describing his set models for Rape of Lucretia as 'absolutely masterly'. ${ }^{5}$ However, I claim, the foundations for these successes with Britten can be seen in two earlier performances: Stephen Spender's Trial of a Judge (1938), produced in a rather tense collaboration between politically-minded Unity Theatre and the more aesthetically-driven Group Theatre, and Edith Sitwell's Façade (1942), a collection of poems set to music by William Walton which had enjoyed previous incarnations as far back as 1922. John Piper took on the role of scenographic designer for both these productions. Britten saw the former production on two occasions and, in 1954, set Sitwell's 'Still Falls the Rain' to music. ${ }^{6}$ While Piper's stage design receives some scholarly and artistic recognition because of its connection with one of the twentieth century's most acclaimed composers, he is largely overlooked as a scenographic innovator in his own right. His earlier work, which forms the basis for this article rather languishes in the archive. This article aims to unearth these designs, reconnecting them specifically with notions of performance. I claim them as both innovative examples of modernist scenography in their own right and as mirrors for Piper's broader artistic intentions.

I use the term "scenography" in the sense defined by Pamela Howard, amongst others, who describes the 'creation of a stage space... always incomplete until the performer steps into the playing space and engages with the audience'. ${ }^{7}$ Using this central idea enables us to temporarily extricate Piper's set designs from his paintings, accentuating the performative qualities of his stage work, and presenting him as a contributor to a British specifically theatrical avant-garde rather than just an artistic avant-garde. ${ }^{8}$

Piper's contributions to these productions graphically illustrate his own aesthetic journey and identify him alongside other Continental painters/set designers. Further, in reading the scenographic designs in conjunction with the dramatic texts and the extant 
comments from collaborators, we begin to grasp the live potential of Piper's work, moving it from paint on a page to a vibrant space of human-driven somatic and aural liveness. His illustration from On the Making of Gardens may demonstrate the intense theatricality of his work, but it is only when we reconnect all the facets of these performances that we can begin to claim him as a central figure in a British avant-garde theatre movement.

The re-emergence of the object: abstraction and landscape in the modernist avant-garde

Piper is often read as a quintessentially English painter, what Alexandra Harris insightfully terms a "Romantic Modern": 'artists who had previously felt compelled to disguise themselves as avant-garde Frenchmen were now to be found on English beaches sheltering their watercolours from the drizzle'. 'During the early 1930s Piper worked extensively with abstraction, sharing the interests of Continental artists like Picasso, Hélion and Mondrian, and British compatriots such as Hepworth, Moore and Nicholson.

A reassessment of his stage work enables even closer parallels to appear between Piper and his European associates, parallels that continue on into the late 1930s and early 1940s, counteracting the claim that he and others had turned their backs on the avantgarde Frenchman persona. The modernist avant-garde was intrinsically interdisciplinary with many individuals working simultaneously in visual art, choreography, music, sculpture, prose, poetry, film and theatre. Many painters branched out into set design. For example, Pablo Picasso designed for the 1917 Satie/Cocteau/Diaghilev collaborative ballet Parade; Bauhaus founder Walter Gropius created intricate (though ultimately unworkable) designs for visionary German theatremaker Erwin Piscator, and Lyubov Popova co-operated with Russian Vsevolod Meyerhold in creating constructivist sets for biomechanical actors.

Britain appeared to rather lag behind the Continental art scene in this regard. As Michael Northen suggests 'it is strange that at this period in Britain serious painters had not been asked to design for the theatre. Abroad artists such as Picasso and Derain, whom Piper so much admired, and who had such a great influence on him, already had many productions to their credit'. ${ }^{10}$ There remained some notable exceptions to Northen's 
proclamation: Robert Medley's work with Group Theatre, for example, or Lovat Fraser's designs for Nigel Playfair's 1920 version of The Beggar's Opera. Yet it would be true to say that, on the Continent, painters, artists, sculptors and architects played more central roles in innovative mise en scéne. Piper's sustained cross-disciplinary contributions to the theatre place him firmly in a category of modernist avant-garde artists from across Europe who engaged consistently with the dramatic mode.

As the 1930s progressed, however, Piper moved away from pure abstraction and towards a resurrection of the object. Partly this was simply an aesthetic choice, but it also connected with the changing context. With the rise of fascism and the onset of another world war, Piper seemed to question the validity of cubist geometry. In his search for art embedded in history and socio-cultural heritage that would transcend the contemporary, Piper, as Harris explains, returned to British beaches and landscapes. Initially this might seem to be a retreat into escapist romanticism. However, as Frances Spalding suggests, 'his commitment to the modern remained'. ${ }^{11}$ Piper's aesthetic decisions were less about dreamy fantasies, and more about celebrating and documenting a changing landscape punctuated with definable objects.

In choosing to design for Spender's production, Piper aligned himself firmly with a politically radical work. The politics of Trial of a Judge are obvious. A thinly veiled critique of Nazi Germany, the play follows the story of the eponymous Judge who presides over a case in which a fascist gang is accused of murdering a Polish Jewish man. Under great pressure from the shadowy authorities the Judge finds the defendants not guilty. However, he later changes his mind, convinced that someone must make a stand against the rising anti-Semitic violence. Imprisoned alongside others who have decided similarly, the Judge is eventually taken away to his death, the Chorus of Red Prisoners concluding with a note of hope: 'We shall be free. We shall find peace'. ${ }^{12}$ The play is an obvious though poetically intricate analysis of contemporaneous Germany.

The politics of Sitwell's poetry are far less easy to discern. Whereas, for all its imaginative poeticism, Trial of a Judge retains a distinctive political edge, Façade initially appears to be a collection of rather odd, obscure poems. Furthermore the first performance took place in 1922, many years before the 1942 version for which Piper designed the front cloth, and during a period of peace and relative affluence. However, while Sitwell was not 
politically engaged in the same way as Spender, she remained politically aware. Privileged she may have been, but, due to domestic issues, she lived a surprisingly precarious economic existence and sympathetically witnessed hunger marches while forcefully condemning rich Londoners who dressed as beggars for so-called 'freak parties'. ${ }^{3}$

Façade (and perhaps to a lesser extent Trial of a Judge) retains a political radicalism that some critics claim is inherent in all difficult poetry. In an intriguingly performative description Leonard Diepeveen not only suggests, as did T.S. Eliot, that difficulty is a defining factor of modernist poetry but that 'difficulty is an odd aesthetic experience; using their whole bodies, people react viscerally to difficulty, often with anxiety, anger and ridicule'. ${ }^{14}$ Such instinctual reactions mean that difficult poetry has a rather paradoxical sense of universalism. Everyone can have such reactions. At the same time, difficult poetry remains aloof and inaccessible, pleasingly useless for dictators looking for inspiration for rousing, jingoistic speeches. As Terry Eagleton suggests in his recent The Event of Literature, 'the obscurity of modernist art is rather like the defensive mechanisms with which Nature has thoughtfully equipped animals in danger of being too easily snapped up by a predator. ${ }^{15}$ The anti-fascist politics of Trial of a Judge are relatively easy to uncover; while Façade is not political in the same way, the radical anti-authoritarian stance of difficult poetry often exudes a subversive under-text.

Describing Piper's art, Hugh Gordon Porteous in an article entitled 'Piper and Abstract Possibilities' published in the 1935 edition of Axis reads his work thus:

The job of the abstract painter, the composer of geometrical forms, should be to relax gradually the rigidity of formal rules until his work admits, more and more, personal factors. ${ }^{16}$

In essence Piper was not simply turning his back on abstraction but, rather, re-imagining it for the contemporary world. According to Porteous, abstraction remains but is interrupted by human elements. Piper's mid-‘30s abstract work often seems to be made up of definable objects - 'buoys, stay sails, masts and hulls of boats ${ }^{17}$ - in keeping with his later turn towards the sea. Further, many of his abstractions contain interruptive elements. His 1934 Construction (Intersection) provides a case in point, the scene containing three diagonal lines acting as pathways moving from downstage to upstage (or vice versa). In the theatre, actors take on this interruptive role, bringing focus and movement 
to the set, just as Piper's lines do in this artwork. ${ }^{18}$ The actor surely represents the most personal of 'personal factors', disturbing the abstraction simply by entering.

Indeed in Myfanwy Evans' (Piper's) 1937 edited collection The Painter's Object, Piper describes his changing understanding of abstraction and the responsibility of art:

The subject in painting since early Picasso is worth chasing. There has been method in its appearance and disappearance, though at first sight it seems as if it has been popping its ostrich head in and out of the hole quite arbitrarily. ${ }^{19}$ Searching for a 'lost valuable object', as his chapter heading claims, it is little wonder that Piper would begin to turn to theatre as an artwork dominated by a dynamic, moving subject. For, in an almost universal sense, theatre intrinsically relies on the (borrowing from Piper's performative description above) 'appearance and disappearance' of the subject, as actors move across the stage, exiting and entering from the frame/wings. In this way, theatre responds to the abstractive loss of the object that Piper felt so keenly. The centrality of the object for all Piper's work confirms the importance of using the term "scenography" as Pamela Howard understands it; the artwork is 'incomplete' until the performer-subject enters. This is obvious in Trial of a Judge with characters exiting and entering the performance space. It remains less clear in Façade with Piper's frontcloth obscuring the actor. However, as I will show, the acousmatic qualities of Façade constantly suggest the object behind the frontcloth in a sonic rather than visual sense.

Ultimately this movement from pure abstraction towards a more subject-oriented form had aesthetic and thematic stimuli. But by presenting his early theatre work as integral to this change, we have a new way into Piper's oeuvre. The actor becomes the interruptive element, providing Piper with a tangible, corporeal iteration of his aesthetic choice to retrieve the 'lost valuable object'.

\section{Watching and hearing: Piper, Spender and Sitwell}

In 1938, John Piper's name appeared on a document entitled The Aim of Group Theatre. $\mathrm{He}$ is cited as a director of this company in charge of 'décor'. The company's objective is clear:

The aim of the Group Theatre is to present plays through the constant collaboration of a group of writers, actors, artists and musicians; and, at the same 
time, to keep in constant touch with its audience through its programme of lectures, exhibitions, and debates of productions. ${ }^{20}$

Piper did not have a purely aesthetic interest in theatre but was fascinated by the way the stage could speak to audiences, the ways that art and idea could unite. In the same year as this pamphlet was published, Group Theatre attempted a risky venture: to perform a production of Stephen Spender's Trial of a Judge at the London home of Unity Theatre.

The production suffered from a complex, tense collaborative process between the aesthetically-driven, dance-oriented Group and Unity, a collection of theatrical experiments coming out of the agitprop Workers' Theatre Movement. Appealing to both groups due to its anti-fascist politics, the project became rather divisive. Indeed, 'Unity members heckled Spender for what they considered to be his liberal retreat into symbolism and mysticism'. ${ }^{21}$ Ultimately it battled with that age-old issue of whether avant-garde aesthetics are inherently decadent and bourgeois, or whether they can be utilised for rebellious political ends. Some seven years later, Group Theatre director Rupert Doone was still clearly troubled by the tension between Group and Unity when he wrote to Piper asking for amendments to John Betjeman's preface for the Penguin edition of the artist's work:

JB has made a mistake in attributing Trial of a Judge to "Unity Theatre"...I am proud that the G.T. was the first theatre company to invite JP to design sets five years before Sadlers Wells. ${ }^{22}$

A reading of the play leaves no doubt about the centrality of the visual. It might be a word-based poetic rendering of fascism, but Trial of a Judge is consistently imbued with a strong sense of the ocular; little wonder then that an artist of Piper's stature should see the merit in creating backdrop structures that could complement the visuality of the play. Resident Group Theatre designer Robert Medley confirmed that 'being more of a nonfigurative than representational artist at the time [Piper] was better suited than I was to provide the abstract architectural settings that Stephen's play required'. ${ }^{23}$ Certainly, for all its clear political objectives, Trial of a Judge is diffused with abstraction. It begins, for example, with 'Lights suggesting illusion and uncertainty', paralleling work by earlier theatremakers like Edward Gordon Craig and Adolphe Appia whose lighting techniques focused on creating atmosphere. ${ }^{24}$ Unity Theatre members accused Group Theatre of apolitical symbolism and, while this charge seems a touch reductionist, certainly the 
symbolic remains vital to a thorough understanding of the play. Spender distinguished his characters using colour; the Black Chorus represents the fascist thugs, the Red Chorus (interestingly, rather than 'White' Spender opted for a more politically charged rebel colour) is the dissenting voice. When the Red Chorus is imprisoned, the ocular clues are ambivalent: 'At first they can hardly be seen through the darkness which gradually lightens, but the stage is never fully light. ${ }^{25}$ Finally the Red Chorus speak their closing refrain - 'We shall be free. We shall find peace' - through the darkness that has once again shrouded the stage. The audience is left wondering whether the hoped for freedom and peace will ultimately be enveloped by the darkness in a moral/ethical sense. Given that Group Theatre performed the play in 1938, such prophetic uncertainty is to be expected.

Stage directions and character-identifying colours are visually suggestive, but the poetry itself also remains discernibly visual in content. As an example, below is a speech from the Fiancée of the murdered man:

Who thanks? And who shall pay

Statesmen who make a literal candle

Of blazing parliaments?

Dons whose learning heaps

The living leaves of art upon a bonfire

In public squares under the eyes of statues

Those lenses of the snow, through death's cold nothing

Staring at madness? ${ }^{26}$

Not only do we find candles, bonfires and 'blazing parliaments', all visual representations of the light (politically and intellectually) the Fiancée searches for, even the statues can see, using snow as a lens. Many passages include a variety of similar, ocular images.

Piper's set responded to the innate visual vibrancy of the poetry and directions. Michael Sidnell's description in his history of Group Theatre, Dances of Death: the Group Theatre of the Thirties, picks up on the visual representation of fascism, alluding to Piper's continual exploration of abstraction's limitations and boundaries:

An abstract Expressionist setting - [Piper's] first design for the theatre - was anything but dreamlike. The brightly coloured, severely geometrical screens and simple, stylized balcony helped to create a powerful - even terrifying - image of cruel and implacable force bearing down upon vulnerable individuals. ${ }^{27}$ 
The set mirrored the themes of the play - terror, cruelty - while simultaneously, for Sidnell at least, working with some of the central techniques of the modernist avantgarde. Certainly the main set resembled a painting by Mondrian with blue, red and white panels. ${ }^{28}$ But it is also interesting that Sidnell should mention expressionism in his description. Trial of a Judge retains a symbolist perspective but also reflects the bleaker, more frightening methods of expressionism. Indeed, one could viably read this play alongside others from the expressionist tradition, for example Masses Man by Ernst Toller (1921), which also focuses on political prisoners, or Sophie Treadwell's Machinal (1928) with the incarceration and execution of protagonist Helen. In theme and form Trial of a Judge can be understood in parallel to specific movements and performances from across the Continental European and American avant-gardes.

In his chapter in The Painter's Object, Piper gives two ways in which the object reappears after almost vanishing in abstract painting. One is the beach, a space readily associated with Piper as his career progressed. But the other is 'a room. Evidently a room, but without any of the room's recognizable qualities, such as a table, or chairs or pictures. This collection [of room experiments] in its whole general form is more or less geometrical, and something like a crystal: but it also has decided amorphous qualities'. ${ }^{29}$ Just a year later, Trial of a Judge gave Piper an opportunity to play with this idea of a room, one of the most potent manifestations of his turn away from pure abstraction. Extant photographs of the room at the Palace of Justice (a key performance space where the Judge resides) show a large ecclesiastical-style chair. However the rest of the room is, in keeping with Piper's propositions above, only suggestive of a room; a large curtain and a semicircular platform stage (rather like those used by the constructivists in Russia or Erwin Piscator in Germany) dominate upstage. ${ }^{30}$

While clearly reflecting Piper's avant-garde perspective, the designs for Trial of a Judge can also be read as part of his turn towards British ecclesiastical architecture. Piper had an enduring love of stained glass, at once appealing both to his passion for nonpictorial art and his unbreakable connection with history and landscape. As David Jenkins and Frances Spalding suggest, 'even while Piper's experience of stained glass pushed him towards pure abstraction, it also stirred his awareness of dialogue between past and present'. ${ }^{31}$ Piper was not alone in his interest in stained glass. Indeed Herbert Read, who enjoyed an association with John and Myfanwy Piper during the Axis years, wrote a 1926 
book entitled English Stained Glass. In it he claims that ancient stained glass directly preempts the intentions and techniques of modern art:

In its finest manifestation abstract art has two characteristics: a delight in formal rhythms for their own sake, and a desire to express a permanence of absolute ideas rather than a fleeting impression of natural forms. ${ }^{32}$

Certainly one can follow Read's point here. Stained glass is largely unconcerned with issues of naturalism. Rather it deals with representation, with image, with emotion, colour and light. Piper's design for Trial of a Judge can certainly be read through his interest in stained glass. While one could follow Medley's conclusion that the set exhibited a certain 'abstract' quality, one could equally imagine it as a painted version of stained glass - block primary colours and outlined shapes - challenging the constraints of naturalist realism. As might be imagined for such an ocular play, Spender includes numerous references to windows. Generally, mirroring the block-painted set, they appear difficult to see through; Government minister Hummeldorf, for example, has to throw the windows open in order to make sense of the scene outside. Spender's stage direction is telling:

During the rest of the act the audience should feel that the actors within the room bave become slightly unreal; that the reality is in the street outside. ${ }^{33}$

Just as Piper's abstract set design brings a sense of non-reality to the production, so windows seem to mark boundaries between the real and the unreal, (theatrically) between realism and abstraction. This reveals a paradoxical element in Piper's work; in recovering the object (in this case the human actor as dynamic intervener in the visual spectacle), it simultaneously disappears. This is a tension that notably appears throughout modernist aesthetics, most influentially in T.S. Eliot's essay 'The Possibility of a Poetic Drama' in which he concludes that the performer is a barrier to the full development of poetic drama as 'the performer is interested not in form but in opportunities for virtuosity or in the communication of his "personality". ${ }^{44}$ For Eliot the individual subject is a barrier to the full realisation of the work. Knowingly or not, Piper plays with this tension, simultaneously encouraging a focus on the performers before obscuring them with the set's 'severe geometry'.

Group Theatre performed the work of many poets/playwrights during the 1930s: Auden, Isherwood, MacNeice, Eliot. In Aspects of Modern Poetry, Sitwell complains about the work of innovators such as Auden and Ronald Bottrall: 
My complaint [against these poets] is that they are almost invariably dull to an unprecedented degree, platitudinous and numb-fingered. ${ }^{35}$

However, she retained more sympathy for Stephen Spender's work, omitting it from the accusatory passages of her 1934 book. ${ }^{36}$ Indeed, the two shared an amicable friendship over the years; Spender and his wife Natasha even asked Sitwell to be godmother for their first child. ${ }^{37}$ In 1942 Sitwell travelled to London from her wartime bolthole Renishaw Hall to watch a performance of her innovative spoken poetry work Façade. While in London she met with Spender and Natasha at the Sesame Club, Grosvenor Square. $^{38}$

Façade has a long and complex history. The first official performance took place at the Aeolian Hall, London in 1923, though it had been presented informally the year earlier. There arose many apocryphal stories about this event, including the claim that Noel Coward stormed out in a fit of pique. ${ }^{39}$ In fact Edith, alongside her brothers Osbert and Sacheverell who contributed significantly to the performative realisation of their sister's work, compared Façade to that influential experiment in modern ballet Parade, hoping for a similar scandal. However, as John Pearson suggests, 'the secret weapon of the English philistine is not aggression but indifference'. ${ }^{40}$ It did attract some praise; Gerald Cumberland of Vogue, for instance, wrote 'I am by no means certain of what some of her poems mean, but if I do not understand their beauty, I divine it, and for that reason am all the more attracted, drawn, seduced'. ${ }^{41}$ Façade is characterised by, in Robert Post's terms, 'strong rhythms, internal and end rhymes, and various types of vowel and consonant patterns, including alliteration, consonance and assonance. ${ }^{42}$ Such vocally stimulating poetry demands performance rather than silent contemplation; these are poems to be read aloud.

By 1942 the context had changed considerably. Sitwell watched fearfully from Renishaw Hall as bombs fell on the streets of Sheffield. Yet, in this new age of total war where the bunkers and trenches encroached on the cities of Britain, Façade found a new following in a performance back at the Aeolian Hall. Walton's music remained in this longer twenty-one poem version and fellow composer Constant Lambert gave the recitation. But the scenic design changed, created by John Piper. 
Piper enjoyed a particularly friendly association with the Sitwell family. The Sitwells greatly admired Piper's work, and Osbert asked him to paint Renishaw Hall in 1940 soon after war was declared in an attempt to capture its rather old-fashioned, establishment grandeur. In a sense Renishaw stood apart from changing social hierarchies and burnt out buildings of the cities. ${ }^{43}$ Piper did not begin the Renishaw paintings until 1942, the same year he painted the Façade curtain. The final paintings have a rather gothic feel, the house stretched out in its austere, turreted beauty. According to Frances Spalding, the history of the house (the architectural changes made according to fashion and the cannonball marks of Civil War combat) meant that, for Piper, the chouse and its setting proved to be rich in incident'. ${ }^{44}$ There is a sense of dynamism, movement and lingering drama at Renishaw Hall despite its aristocratic, establishment air. That this house and landscape should be described in such a manner immediately reminds us of the nature of theatrical art where architectural objects are actively and intentionally interrupted and disturbed by human interaction. My central concept of scenography, the understanding of performative space as 'not merely transformed through the mechanical devices of the stage but also by the presence and movement of live actors whose own performances are unstable, ${ }^{45}$ seems to describe the historiography of Renishaw Hall as much as it does the onstage performances of Trial of a Judge or Façade.

Whereas Trial of a Judge enjoys an innate sense of the visual, Façade focuses on the audible, on the spoken word, sounds and musical rhythms. Just as Spender's play contains frequent references to seeing, the poems of Façade are punctuated by images about hearing. The poem's titles often enforce the musicality of the piece: "Hornpipe", "Lullaby" and "Jodelling Song". Paralleling the futurist or dadaist challenges to logical language we also find musical trills ("Polka"). Further, Sitwell impels inanimate objects to make noises - 'light is braying like an ass' ("Trio"). ${ }^{46}$ The poems contain musical rhythms and rhymes, and remarkable use of audible devices such as assonance: the 'gloria', 'boreatic', 'memorial', 'floreal' of "Hornpipe". ${ }^{47}$ These are poems to be performed and heard, a fact compounded by Walton's remarkable musical accompaniment.

Initially, then, it might seem rather incongruous to ask Piper to orchestrate the visual scenographic elements at all. However the Sitwells venerated painters for their powerful capacity for insight; the year after Piper's work on Façade, Edith Sitwell wrote to Myfanwy Piper: 
What lively minds painters have. I am always struck by that. Is it perhaps because if one lives visually one is more en rapport with the universe, than if one lives orally $?^{48}$

Sitwell's admiration for painters (and for painters like Piper in particular) rested on their ability to see the world differently, to comprehend its variety, dynamism and visual beauty. While Piper's frontdrop for Façade is strikingly different from his paintings of Renishaw, it still contains a similar intention: to search for visually vibrant ways of depicting the world. And, as with Piper's designs for Trial of a Judge, one can discern his own personal artistic transitions. However, whereas Spender's play is populated by obvious subjects/characters, the subject in Façade is intentionally less identifiable. In her programme notes, Sitwell contends that the frontcloth not only covered the 'ugly' Sengerphone (the papier-mache megaphone through which the performer recited the poems) but also could 'deprive the work of any personal quality (apart from the personality interest in the poems and music),. ${ }^{49}$ While Piper searched for the returning object in art, Sitwell seemed to be rejecting the visual object entirely. However, her note reflects her own way of understanding the subject: not visually but audibly. It also taps into an interest in, using Maud Ellman's term, 'the poetics of impersonality' that compelled many key modernist figures. ${ }^{50}$ The simultaneous obscuring and revealing of personality is central to the aesthetics of both Trial of a Judge and Façade. This, as Rochelle Rives suggests, is a problematic conundrum and yet offers 'the potential for liberation, ${ }^{11}$ in Façade's case, the opportunity to concurrently obscure the visual in order to elevate the aural.

Façade taps into a particular modernist preoccupation with sound and noise, a 'sonic modernity' as Adrian Curtin describes it in his recent Avant-Garde Theatre Sound, 'giving rise to a plethora of acoustemologies and sound-related developments that informed what it meant to be "modern", ${ }^{52}$ Sound poetry experiments by figures like futurist F.T. Marinetti, Hugo Ball, Kurt Schwitters and others confirmed the importance of the audible. However, borrowing Sam Halliday's phrase, the 'visuality of listening' remained as important as the transmission of sound waves to the ears. ${ }^{53}$ This is helpful when considering Piper's contribution to a primarily audible project. In fact Tim Barringer (who also sees the importance of the visual when discussing Sitwell's poems) even goes as far as to refer to Façade as 'a pioneering English modernist Gesamtkunstwerk' thereby placing the work decisively into a particular Continental European avant-garde mode. ${ }^{54}$ 
Piper's design for Façade contrasts with earlier artistic renderings in a number of key ways. In Frank Dobson's 1923 frontcloth, commissioned by Osbert, the face keenly resembles Sitwell's own. This is surrounded with colonnaded pillars, a plant in the foreground and the word 'Façade' written in non-linear fashion around the chin. ${ }^{55}$ Famed futurist Gino Severini's frontispiece for the 1922 published version shows two commedia dell'arte figures traipsing through the snow. ${ }^{56}$ Severini's work was recommended by Sacheverell; the Italian had already produced images for the Sitwell's magazine Wheels (1920) and had designed the murals for the family's Italian castle Montegufoni (1921) in the preceding years. The 1922 frontispiece is a very different image from the one imprinted on Dobson's cloth, emphasising the playful theatricality of the poems while retaining a rather poignant sense of arduous journeying. Indeed, it markedly resembles the commedia dell'arte images in the Montegufoni murals. In the text for Façade Sitwell juxtaposes light-hearted jocularity with the laborious toil that always defines interaction with difficult poetry, and Severini's illustration mirrors this collocation of reader experience.

Piper's version is altogether different. Centre is a bearded male face, resembling a Roman statue. Stage right is a dark fairytale forest, punctuated by the red vibrancy of the leaves and the wings of the butterfly. In the background is a substantial building, perhaps a church. Stage left is altogether lighter with the moon casting beams on the water and an imposing turreted edifice at the back. ${ }^{57}$ As with the earlier production, the poems were performed through the hole (the face's mouth) using a Sengerphone.

By positioning the performer behind the artwork and Sengerphone, Façade can be partly read alongside a range of modern innovations (most notably the radio) described as 'acousmatic', that is defined 'by the invisibility of sound sources to those that hear them' ${ }^{58}$ This could be read as an attempt to address the issue Eliot revealed in 'The Possibility of a Poetic Drama'; the obscuring of the performer could enable the audience to more clearly attend to the poetic elements. Certainly Piper's frontcloth adds to this acousmatic feel, preventing the audience from really seeing the performer. However, the intense visuality of the work remains despite this acousmatic characteristic. The poems are littered with reference to dances - polkas, tarantellas, waltzes. And there is the constant repetition of colours, particularly in connection with animals - the 'rim of the 
sky hippopotamus - glum' ("When Sir Beelzebub”) ${ }^{59}$ and 'zebra'd black and white' ("Trio"). ${ }^{60}$ Certainly the vocal remains the dominating element, but the visual must have been striking in its innovative design.

Examining the curtain one cannot fail to see the similarity between the building depicted in it and Piper's sketches of Renishaw Hall; Barringer describes it as an 'opulent, melancholy dreamscape... a Surrealist re-imagining of the gardens of the Sitwell's ancestral home'. ${ }^{61}$ So, while the set exemplifies the modernist fascination with unusual sound, it can just as easily be read as emblematic of Piper's interest in painting the British landscape; there are similarities with acousmatic avant-gardism and the painter's aesthetic transitions.

Further, I suggest, the set visually pre-empts much of Piper's later work. Indeed, differentiating it from Frank Dobson and Gino Severini's earlier designs, Barringer describes Piper's curtain as revealing the 'elegiac, neoromantic poetics that lie at [Façade's] heart'. ${ }^{2}$ This is noticeable not only through the buildings and butterflies but also through the central face. It reminds us of Piper's far later fascination with foliate heads. His interest in foliate heads seems to have begun in the 1950s with his preoccupation with the pagan "Green Man" on the one hand and carved ecclesiastical images on the other. These heads have the distinctive features of the central figure in his Façade curtain curled hair, large eyes, leaf-like features. While his foliate head phase may have come later, I suggest that the Façade artwork marked a noticeable origin point for this image. Reflecting on Piper's continued use of the foliate head, Myfanwy Piper suggests that wherever it appeared in her husband's oeuvre it 'is never without the mystery or vitality of its origin'. ${ }^{63}$ Using such an image for the earlier Façade, Piper brings an incantatory, magical mysticism to Sitwell's poetry thereby juxtaposing avant-garde language games with ancient ritual much as dadaist Hugo Ball did in his sound poems at the Cabaret Voltaire. Reading Piper's later foliate heads through his 1942 work on Façade also incorporates these spiritualised ritual figures in a distinctly scenographic genealogy; in a sense this new lineage compels us to 'give a voice' to the foliate head work. It imbibes these later lifeless faces with an aural theatricality and represents them as potential masks covering a dynamic, sentient face underneath rather than inanimate objects in and of themselves. 


\section{Conclusion: poetry in performance}

John Russell rather apologetically confirms the importance of understanding Piper's work in light of the theatrical:

I even think, though once again I have no warrant for saying so, that many of John Piper's collages and abstract paintings have that particular tension that belongs to the kind of perfectly conceived and very well executed "flat" that seizes the attention of a full house in the theatre and leaves us in no doubt that something extraordinary is about to happen. ${ }^{64}$

This theatrical sense of anticipation is, I suggest with Russell, one of the defining factors of Piper's canon. The centrality of the performative, and particularly the expectation of liveness Russell alludes to here, brings an added sense of excitement to Piper's work, whether the geometrical shapes of the early 1930s or the subjectively constructed landscapes of 1938 onwards. Examining Piper's early theatre work enables a far more thorough reading of his innate artistic theatricality, providing a more complete view of his canon and placing him alongside other artists experimenting in the theatrical avantgarde.

With thanks to the Marc Fitch Fund whose generous grant enabled the completion of this study, and to Faye Hammill for her insightful reading of earlier drafts.

\footnotetext{
${ }^{1}$ Sir George Sitwell, On the Making of Gardens (London: Dropmore, 1949)

${ }^{2}$ John Russell and Tim Barringer cite Autumn at Stourbead (1939) as an intrinsically theatrical painting (Tate, John Piper (London, Tate: 1983), p.15: Tim Barringer, "Façades for Façade: William Walton, Visual Culture and English Modernism in the Sitwell Circle" in British Music and Modernism 1895-1960, ed. By Matthew Riley (London: Ashgate, 2010), p.143).

${ }^{3}$ Tate, John Piper, p. 15

${ }^{4}$ Myfanwy Evans (ed.), Axis: a quarterly review of contemporary abstract art and painting 4 (November 1935), p.12.

${ }^{5}$ Benjamin Britten, Letter to John Piper, 25 April 1946 in John Piper Archive, Tate Gallery. Their mutual affection and admiration remained until Britten's death in 1976. Immortalising their friendship, Piper's 1979 memorial window at Aldeburgh parish church celebrates Britten's achievements by visually portraying the composer's Church Parables.
} 
${ }^{6}$ Paul Kildea, Benjamin Britten: a life in the twentieth century (London: Penguin, 2014), p.303, p.405.

${ }^{7}$ Pamela Howard, What is Scenography? (London: Routledge, 2009), p.xxiv.

${ }^{8}$ see Claire Warden, British Avant-Garde Theatre (Basingstoke: Palgrave, 2012).

${ }^{9}$ Alexandra Harris, Romantic Moderns (London: Thames and Hudson, 2010), p.10.

${ }^{10}$ Tate, John Piper, p.31.

${ }^{11}$ Frances Spalding, John Piper Myfanwy Piper: lives in art (Oxford: Oxford UP, 2011), p.93.

${ }^{12}$ Stephen Spender, Trial of a Judge (London: Faber and Faber, 1938), p.115.

${ }^{13}$ Richard Greene, Edith Sitwell: avant garde poet, English genius (London: Virago, 2011), p.199.

${ }^{14}$ Leonard Diepeveen, The Difficulties of Modernism (London: Routledge, 2003), p.xiv.

15 Terry Eagleton, The Event of Literature (London: Yale UP, 2012), p.185.

${ }^{16}$ Evans (ed.), Axis, 15.

${ }^{17}$ David Jenkins and Frances Spalding, John Piper in the 1930s: Abstraction of the Beach (London: Merrell, 2003), p.30.

${ }^{18}$ Scarborough Art Gallery, John Piper, 1903-1992: a retrospective (Scarborough, 1993), no. 5.

${ }^{19}$ Myfanwy Evans, The Painter's Object (London: Gerald Howe, 1937), p.69.

${ }^{20}$ Rupert Doone; Stephen Spender; Benjamin Britten; Brian Easdale; Robert Medley and John Piper, The Aim of Group Theatre (1938).

${ }^{21}$ Colin Chambers, The Story of Unity Theatre (London: Lawrence and Wishart, 1989), p.147.

${ }^{22}$ Rupert Doone, Letter to John Piper, 26 January 1945 in John Piper Archive, Tate Gallery.

${ }^{23}$ Robert Medley, Drawn from a Life (London: Faber and Faber, 1983), p.167.

${ }^{24}$ Spender, Trial, p.13.

${ }^{25}$ Spender, Trial, p.111.

${ }^{26}$ Spender, Trial, p.55.

${ }^{27}$ Michael Sidnell, Dances of Death: The Group Theatre of London in the Thirties (London: Faber and Faber, 1984), p.231.

${ }^{28}$ Jenkins and Spalding, John Piper in the 1930s, p.154.

${ }^{29}$ Evans, Painter's Object, p.72.

${ }^{30}$ Tate, John Piper, 31; John Sutherland, Stephen Spender: a literary life (Oxford UP, 2005), plate 15.

${ }^{31}$ Jenkins and Spalding, John Piper in the 1930s, p.35.

${ }^{32}$ Herbert Read, English Stained Glass (London: Putnam and Sons, 1926), p.5.

${ }^{33}$ Spender, Trial, p.46.

${ }^{34}$ T.S. Eliot, 'The Possibility of Poetic Drama' in The Sacred Wood (New York: Alfred Knopf, 1921), p.62.

${ }^{35}$ Edith Sitwell, Aspects of Modern Poetry (London: Duckworth, 1934), p.234.

${ }^{36}$ Sitwell Aspects, p.229.

${ }^{37}$ Greene, Edith Sitwell, p.312.

${ }^{38}$ Greene, Edith Sitwell, p.290.

${ }^{39}$ Greene, Edith Sitwell, p.168. Whatever the truth of this claim the event certainly influenced Coward in his writing of London Calling (1923) in which he creates the caricatures of the Family Whittlebot: the poetess Hernia and her two brothers Gob and Sago. The thinly veiled representations of the Sitwell family are unmistakable and caused an acrimonious rift.

${ }^{40}$ John Pearson, Façades (London: MacMillan, 1978), p.182.

${ }^{41}$ Richard Greene (ed.), Selected Letters of Edith Sitwell (London: Virago, 1997), p.453. Façade enjoyed some later performances too. Perhaps the most successful was a 1928 version at the International Festival of Modern Music on Siena (Greene, Edith Sitwell, p.202). In 1947 the BBC broadcast a version, while in 1949 it made its way to MOMA, New York with brother Osbert Sitwell introducing and Edith Sitwell reciting. The MOMA version seemed particularly successful with Philip Hamburger writing in the New Yorker, 'to me it was wise and wonderful art' (Pearson, Façades, p.403).

${ }^{42}$ Robert Post, 'To read as a poet: major performances of Edith Sitwell', Text and performance quarterly, 11: 2 (1991), p.133.

43 Spalding, John Piper Myfanwy Piper, p.204.

${ }^{44}$ Spalding, John Piper Myfanwy Piper, p.213.

45 Arnold Aronson, Looking into the Abyss: essays on scenography (Ann Arbor: Michigan UP, 2005), p.5.

${ }^{46}$ Edith Sitwell, Façade and Other Poems (London: Duckworth, 1971), p.89.

47 Sitwell, Façade and Other Poems, p.115.

${ }^{48}$ Edith Sitwell, Letter to Myfanwy Piper, 10 Dec 1943, John Piper Archive, Tate Gallery (1943).

${ }^{49}$ Edith Sitwell, Programme notes for 'Façade' (1942)

http://www.auricleensemble.org.uk/pdfs/Facade $\% 20$ programme $\% 20$ Lyric $\% 20$ Hammersmith $\% 20$ with $\% 2$ 0Constant $\% 20$ Lambert.pdf [accessed April 1 2014]. 
${ }^{50}$ Maud Ellman, The Poetics of Impersonality (Cambridge: Harvard UP), 1987.

${ }^{51}$ Rochelle Rives, Modernist Impersonalities: affect, authority and the subject (Basingstoke: Palgrave MacMillan, 2012), p.4.

52 Adrian Curtin, Avant-Garde Theatre Sound: staging sonic modernity (New York: Palgrave MacMillan, 2014), p.9.

53 Sam Halliday, Sonic Modernity (Edinburgh: Edinburgh UP, 2013), p.3.

${ }^{54}$ Barringer, "Facades for Façade", p.127.

55 Gerald Cumberland, 'Façade: a new entertainment', Vogue (1923), p.36.

${ }^{56}$ Edith Sitwell, Façade (London: Favil Press, 1922).

57 Tate, John Piper, p.56.

${ }^{58}$ Halliday, Sonic Modernity, p.100.

${ }^{59}$ Sitwell, Façade, p.117.

${ }^{60}$ Sitwell, Façade, p.88.

${ }^{61}$ Barringer, "Facades for Façade", p.143.

${ }^{62}$ Barringer, "Façades for Façade", p.145.

${ }^{63}$ River and Rowing Museum, John Piper: master of diversity (Henley on Thames: Rowing and River Museum, 2000), p.28.

${ }^{64}$ Tate, John Piper, p.15. 